\title{
The social accumulation of violence in brazil: some remarks
}

\begin{abstract}
Since the 1980s, a long historic and social process has transformed Rio de Janeiro, the so-called "Marvelous City"that enchanted the world in the 1940s, '50s and'60s, into a city presented in the international media as one of the world's most violent. How was this possible? What took place for this transformation to occur and produce effects that remain until today, more than thirty years later? The objective of this article is to examine some hypotheses for the advance of violence based on the use of firearms in Rio de Janeiro. These hypotheses are combined in the conception of a "social accumulationof violence,"which the author has been developing in his work.1-5 This process began in Rio de Janeiro and has spread to all large or medium Brazilian cities from the Brazilian South to Northeast, although recently there are important inflections in some Southeastern states. In the past twenty years, nearly one million people have been murdered in Brazil, most of them young. A diffuse violence accompanies these deaths, migrating from city to city, from one region of the country to another, with no significant decline in the national statistics.
\end{abstract}

Keywords: violence, police, thefts, illegal gambling, fraud, judicial system
Volume I Issue 2 - 2017

\author{
Michel Misse \\ Department of Sociology, Federal University of Rio de Janeiro, \\ Brazil
}

Correspondence: Michel Misse, Department of Sociology, Federal University of Rio de Janeiro, Brazil,

Email michelmisse@gmail.com

Received: July 24, 2017 | Published: August 24, 2017

\section{The origins}

To better situate what we will present in this article, it is necessary to consider some preliminary data. Until the mid 1950s, the city of Rio de Janeiro, then capital of Brazil (known as the federal district) did not have a rate of more than 8 homicides per 100 thousand people, a rate lower than New York City at the same time. Rio de Janeiro had 2.5 millionresidents and since the 1940s had been receiving a growing number of immigrants from other Brazilian states, who came to find work in the capital or in its urban periphery. The majority of the daily crimein the city and surrounding region involved small thefts, illegal gambling, fights with wounds and fraud. There were also a small but generally under reported number of rapes and violence against women, as well as attempted homicides and violent conflicts in bars and public places. Illegal drug sales were insignificant, far overshadowed by smuggling - the main illegal market at the time along with the "jogo do bicho", (animal game), a popular lottery that has existed for more than a century and that has always been illegal. ${ }^{6}$ Police corruption is one of the main legacies of the jogo do bicho. However,mostof the crimes against life at the time were crimes of passion, which were nearly all crimes linked to honor and to "machismo," since this was a traditional society just beginning to modernize. The literature of the period presents an expressive narrative of these issues, while more contemporary literature is characterized by the irruption of violence in the characters of these narratives. There is a sharp rupture between the passionate anguish of Nelson Rodrigues' charactersof the 1940sand '50s, who killed and were killed out of jealousy and other emotional obsessions, and the nearly ethnographic characters of Paulo Lins in the 1960s and 1970s, whose book became the film "Cidade de Deus" [City of God].

Since the second half of the 1950s, an increase has been perceived in urban criminality, with the rise of gangs that rob gas stations, taxi drivers and shops. There is a higher record of violent crimes, and homicides reached a rate of 10 per 100,000 residents. The press ran headlines comparing Rio de Janeiro to Chicago of the 1920s and demanded an immediate response from the police to the sense of insecurity that the press itself helped to disseminateinthe city. The reports in the daily newspapers, magazines and radio stations concentrated on the faits divers that began to show a city in which crime modernized along with urban life. But compared to what began to happen thirty years later, the city could be characterized as a peaceful metropolis. This was the social representation that its population still had of their city, but which began to be lost.

The police,as was customary,was led by an army general who given the clamor in the press decided to create a special squad to deal with new problems. This group, through their arbitrary and violent actions, came to be known popularly as the "death squad,"a name that became popular internationally. Throughout the 1960s it was held responsible for the death or imprisonmentof various criminals. Its fame increased with the death of its leader, detective Le Cocq,in 1964 and the creation by his followers of the "Escuderie Le Cocq", which was driven according to the press of the time by violent, vindictive andat times illegal action. In various cities of the metropolitan region groups began to appear of "justiceiros" [vigilantes], which were known as "exterminator groups" who offered private security to shop owners and local small businesses with the promise of eliminating"(by death) the muggers or small thieves who worked there.

A large rebellion in 1960 in Rio de Janeiro's main prison, the first in a series that was repeated in the following decades, was crushed by police forces, but would serve as a reference for the changing standard of urban crime that followed the 1950 s, with the gradual disappearance of the figure of the "malandro"." With his departure from the scene,

'Malandro is an attribute used to designate a person or a lifestyle (malandragem). Its origin is Italian (malandrino) and its more universal content is that of the Iberian picaro. In $19^{\text {th }}$ century Rio de Janeiro the term malandro came to represent a social type between a black slave and a free worker who avoided regular work, substituting it for a hedonistic life based on advantages obtained from gambling, at times exploitation of women. 
the malandro would gain a slightly positive and nostalgic social representation in samba and literature in following years, and was substituted, by contrast, by the figure of the "marginal,"whose referent was a fusionof the sociological notion of the individual placed at the marginof the socio-economic system with the notion of the individual at the marginof the law. In contrast to the malandro, the marginal was depicted as a violent, rough, stupid and homicidal social type. Both, however, were interpreted as coming from the same poor social milieu, the favelas of the capital and the sub-divisionsof immigrants from the Brazilian Northeast, in the periphery of the city formed by the metropolitan region. Thus, social types of criminal subjects were formed.

In the 1970 s, the homicide rate in Rio reached 20 per 100 thousand and the sense of insecurity increased considerably in the years following the military coup that imposed a dictatorship on Brazil in the mid 1960s. Torture, whichwas tolerated for common criminals as a means to attain confessions for crimes since the colonial period, also came to be used by the political police and by the military to repress civil political resistance to the dictatorship. The situation as a whole deteriorated even more with the entrance of the Military Police, a state-level force based on a military model, used for policing the streets of the city, to substitute the "guarda civil"or municipal guard, which no longer existed. With an increasing force each year, the Military Police became responsible for street policing and repression of crime in the streets, which had been the responsibility of the civil police, which came to specialize in the investigation of crimes and only worked as a policeforce for the judicial system. The separation and the tension of attributions between the two police forces would become increasingly deeper, reaching a maximum today, with the civil police criticizedfor low productivity and the military police of highly lethal militaristic actions.

A study that I conducted in the 1970s and ' 80 s found in statistics for juvenile justice in Rio de Janeiro the passage from one standard to another for crimes against property. In the second half of the 1970 s, the crimes involving violence or its threat (robbery) began to grow and would exceed crimes against property that did not involve violence (thefts). ${ }^{1}$

Urban guerrillas were formed to fight the dictatorship in the last years of the 1960s and the early 1970s and began to rob banks to finance their armed struggle. Common criminals, the "marginals", who had previously assaulted supermarkets and gas stations, also began to rob banks. The military regime implemented the National Security Law, which treated armed political opponents and radicals in the same way as common criminals and in the mid 1970s they shared common spaces in the penitentiary system. Some of the jailed common criminals then began to distinguish themselves from the "marginals", whether because they had a better level of education, or because of respect they had earned for having robbed banks, or because they began to approximate themselves to the political prisoners and to imitate their capacity for unity and mutual support. For this reason, they began to be called by the prison guards by the name of the "os lei de segurança" [The Security Law gang]. ${ }^{7,1}$

They organized, and when an amnesty for political prisoners was implemented in the last years of the dictatorship, the amnesty decree did not benefit these common criminals who had been convicted under the same national security law that had condemned the political prisoners. Upset, the common criminals created an organization, the "Falange Vermelha" (the word red was a reference to the radicals of the left) and demanded "peace, justice and liberty."The first, and at the time the most important and violent criminal organization in Brazil was created, the CV "Comando Vermelho" [Red Command]. Others followed in the 1980s, such as the "Terceiro Comando" [Third Command] (TC) and the ADA (Amigos dos Amigos) [Friends of Friends]. All of these organizations arose within the penitentiary system, they invested in drug trafficking whenthe price of cocaine fell in the market and its offer in Rio de Janeiro and São Paulo increased extraordinarily, after the entrance of Colombia in the production. ${ }^{1}$ In the late 1970s they began to control, through the formation of networks of owners of points of retail sale of cocaine and marijuana in many favelas of Rio de Janeiro and the metropolitan region, with groups of men armed to the teeth. ${ }^{8}$ Each network was supported by one or another of the penitentiary"commands," which were the press called the "trafficking factions," the CV and the TC and later the ADA. The arms race between these gangs led to a homicide rate that was already 30 per 100 thousand in the mid 1980s and reached 60 per 100 thousand in 1994

An examination of the profile of the main armed actors in Rio de Janeiro from the mid 1990s until today can help us to understand the main dimensions of the social accumulation of violence.

\section{The main collective actors of violence in rio}

A ponderable portion of homicides and other violent crimes in Rio de Janeiro do not involve criminal groups or collectives. The violence against women or conjugal or domestic violence often exceeds it, in private and family life. Robbery, sexual crimes, fights that lead to wounds involving more than one assailant are less common and involve small groupings that are nearly always occasional. For observers of the police and judiciary, as well as for specialists in public safety, mostof the violent crimes in Rio de Janeiro are directly or indirectly related to three types of collective actors:

a) Those who act directly in illegal markets, mainly the factions of illegal drug trafficking that control points of sale in favelas and other poor urban regions.

b) Those that organize extermination groups and militias to extort residents of unsafe areas.

c) Police and other public employees who, in the exercise of their profession, offer protection to traffickers and other agents of illegal markets in exchange for eventual bribes or regular payments.

\section{The wholesale drug networks in favelas}

What characterizes the Movimento [The Movement], the name given to drug sales in Rio de Janeiro, and distinguishes it from the drug sales in other cities, is the relative local organization, its proto political pretensions, its capacity to re-organize locally, and mainly to establish horizontal networks for mutual protection. Different from retail drug sales in large cities of other countries, the movement is not directly subordinated either to the large wholesalers or to vertical organizations of a family or patrimonial base, such as mafias. Although its local organization often has a family-base in the key retail positions, it rarely goes beyond the owner or the "general manager" of the business. On the other hand, the organization of the networks is more fragmented and vulnerable than is often thought.

How then was such a large accumulation of groups and networks in Rio de Janeiro in the past three decades possible, without this growth 
involving the subordination of the movement to strategic organized crime groups (mafias, cartels, etc.)? At the end of the 1970s and early 1980 s, a type of association began within prisons that is known today as a "faction"or "command"and that wound up establishing horizontal mutual protection networks between local drug chiefs in the Rio de Janeiro favelas. It was exactly at this time that the drug trafficking groups gained strength and began to stand out in the composition of Rio de Janeiro's "urban violence."

Before that time, the sale of marijuana in Rio de Janeiro favelas was insignificant, and accepted by the local population, and did not involve a high level of violence or confrontational relations with the police. The point of inflection in the local dynamics of the retail drug sales was due to the introduction of cocaine in these networks in the 1970 s, and more intensely during the 1980s. This took place after the entrance of Rio de Janeiro and São Paulo in international cocaine trafficking routes from Paraguay and Bolivia to Europe.

The initial capital invested by the pioneers of cocaine trafficking did not come from marijuana sales, given that its profitability was low, but to robberies committed during the 1970s of banks and companies. The practice of large robberies disseminated among common criminals based on the "demonstration affect" of the actions of this type by the urban guerrillas fighting the military regime. Nevertheless, these crimes had become increasingly more difficult to carry out, due to the intensification of the police repression on the crime gangs and the improvement of security measures adopted by private companies. Partof the capital accumulated in large thefts was invested in cocaine dealing, which was possible due to the associations established between bank robbers and owners of the so-called "bocas de fumo ${ }^{2}$," during the period of their imprisonment.

Within these institutions, the demands of political prisoners for better conditions stimulated the other inmates to also organize themselves politically due to the poor conditions of incarceration to which they were submitted, revealing once again the "demonstration effect"of the guerrilla movement. The Falange Vermelha was created in about 1979, as a collective that proposed to promote solidarity among prisoners, reduce the violent resolution of conflicts between them and struggle for better conditions within the prison institutions. The political amnesty declared in that same year benefitted only the political prisoners, which encouraged the members of the Falange Vermelha to justify their organizations on political grounds, to neutralize their criminal practices. ${ }^{9}$ Throughout the 1980 s, members of this collective gained their liberty and the Falange Vermelha wound up expanding its influence through Rio de Janeiro. The connections that had been formed among the criminals helped strengthen the illegal drug dealing networks and the profits of trafficking multiplied due to the growth of cocaine sales. It was then that drug trafficking became the main economic activity of the Falange Vermelha. Even so, the coexistence in prison spaces continued to be a determinant for the articulation of this criminal collective, so that the dispute among the prisoners gave origin to other collectives today known as "factions" or "commands such as the Falange do Jacaré, the Falange da Zona Sul, etc. [Jacaré and Zona Sul are geographic regions].

There are now two main factions that dispute controlof drug sales in the favelas, the Comando Vermelho (CV) and the Amigos dos Amigos (ADA). The first is a direct descendent of the Falange Vermelha, to the degree that the latter was derived from a fissure of the

2"Boca de fumo" literally means "mouths of smoke" and is the expression widely used for the points of drug sales.
Terceiro Comando (TC) which had come from the Falange do Jacaré into two competing factions: the Amigos dos Amigos and the Terceiro Comando Puro (TCP)[Pure Third Command]. Nevertheless, over the decades, the ADA prevailed over the TCP and came to encompass mostof its areas.

The centrality of drug dealing in the articulation of these collectives helped to have the factions constitute themselves as societies among the so-called "donos do morro," [hill bosses] as the local drug dealing bosses were known. This promoted the division of the territories of the favelas into areas under the influence ofone or another of these collectives. The alliances sealed by the faction served to support the monopoly of the donos do morro over the drug sales in certain territories, through the offer of support against eventual invasions by enemy dealers andof a mutual commitment of respect for local authority of the allied donos do morro. In this way, the factions established themselves as horizontal mutual protection networks aimed at the articulation of the defense of their areas of commercial operation, that is: a group of alliances between local drug dealers. Unlike the vertical formations observable in mafias and cartels, there are no leaders above the donos de morro, with the hierarchy of dealing being, above all, local. , $10^{10}$

The weapons used to protect the bocas de fumo also customarily belong to the dono do morro, and in a precautionary system, are left under the responsibility of their men. Some should remain in use at the boca, and be passed to the dealers who enter for each shift; while others are always left with some members of the firm, who can even use them to conduct robberies. There are also guns that are buried in secret locations to protect them from theftor seizure by the police. The weapons are highly valued in the illegal market, so that the unjustified $\operatorname{loss}^{3}$ of a weapon requires that the loss be paid back to the firm. If someone cannot pay back for a lost weapon - if it is a rifle, for example they can lose their life. The weapons, particularly those of high caliber, take on great importance in the conformation of the normal routines of drug dealing. Although the support offered by alignment with a faction allows a relative reduction of disputes for territories and the maintenance of local power relations, there are constant threats from the police, enemy factions or even internal groups within the same firm. Since large quantities of money, drugs and weapons began to circulate in the bocas de fumo, the donos de morro came to invest a significant portion of their profit in thepurchase of weapons and in the payment of bribes to the police. It was also necessary to increase the contingent of dealers, so that "soldiers"would work in the security of the points of sale.

The local power relations and the articulation of the defense of the territories belonging to the donos de morro - and consequently, the faction to which they are associated depends on the formation of these armies of armed men and their obedience and unconditional respect to the "boss". Therefore, there is great distrust among the dealers and much obedience and respect is conquered through subjugation by the use of force ${ }^{4}$, it is also essential that the hierarchy of trafficking be legitimate from the perspective of the traffickers themselves. ${ }^{4}$

\section{The police}

The constitution of the illegal drug market under the format examined above should also be understood based on the relations

${ }^{3}$ The justifications accepted are imprisonment or death of the carrier of the weapon as long as he was working for the traffickers. Losses of weapons in assaults or other private operations must be paid back.

${ }^{4}$ See Silva. About "violent sociability". 2008. 
established with the state agents responsible for social control, especially with police institutions. Although the territorial disputes among dealers are the initial motivation of the arms race found in the retail drug networks, the dynamics of conflict and negotiation between the police and dealers also certainly intensify the violence related to trafficking. It is even possible to also classify the police as a violent actor, considering the way that it operates in Rio de Janeiro, whether through institutionalized or illegal practices. Police violence is a constant theme and also affects the routine of city residents, and directly influences the way that the networks of criminality operate.

There are many charges that agents of both the Military Police responsible for patrolling the streets - and the Civil Police responsible for investigating crimes practice homicides, abuse of authority, torture, extortion or are even members of the criminal groups. But the problem of police violence is not limited to the operation of bad agents who infringe the norms of their institutions. Even the protocols of institutionalized action are propitious to violations of civil rights of citizens and instigate violence. These are highlighted by frequent confrontations between the police and criminal suspects, which spark shootouts in public spaces of the city, particularly in the favelas, and result in lethal victims. The majority of them are due to an official crime fighting strategy, based on police operations aimed at imprisonments and seizures.

The police repression of drug dealing acts in a determinant manner over the regulation of the daily dynamics of this market. There are two principal forms of relationship between drug trafficking and the police: confrontations and the relations of bribery and extortion. These related forms are associated to the fact that the trafficking actions are territorialized and sedentary, establishing fixed and recognizable points of sale, which facilitates their identification by drug consumers, although also by the police. To protect their men, arms, drugs and money from police operations orfrom rival factions, the dealers use large weapons to defend their territories. Nevertheless, the superiorarmed power of the state impels the traffickers to negotiate the reduction of police repression, paying the corrupt agents of the civil and military police to not invade the favelas in armed conflict.

In this way, it is possible to affirm that the administrative modelof the territories used by the dealers on the hillsides involves the need to buy "political merchandise". "Political merchandise" refers to "all merchandise whose production or reproduction depends essentially on a combination of political costs and resources, to produce a political or economic exchange value". ${ }^{1}$ This concept has been quite useful for considering how public agents privately appropriate power that is delegated to them by the state to obtain monetary gains. The sale of the reduction of police repression by the partof corrupt agents is one of the best known examples of the transaction of "political merchandise" in the case of Rio de Janeiro. ${ }^{4}$

The payment of the bribe does not guarantee that the police will comply with the agreementbecause orders from superior levels can oblige police squads to undertake a police operation despite the illegal agreements that had been established. It should be added that the police are not cohesive institutions, for which reason some police officers accept bribes and others do not. A habitual consequence of these police operations are the so-called "autos de resistência"[registers of resistance], which is the classification that the police give to the homicides committed by police officers in service in supposed legitimate defense. The volume of suspects killed inpolice operations in Rio de Janeiro in the past decade is startling and without parallel inother Brazilian cities and even in the Americas or other parts of the world. Since 2007, there was a drop in these numbers, although this was compensated for by a continued increase in the number of disappeared people, while it is not known if they will reappear or were killed. ${ }^{5}$

\section{Militias}

In 2006, the press revealed the existence of groups of state agents who controlled neighborhoods, favelas and housing projects. These agents charged "protection" fees from residents and exercise amonopoly over some economic activities such as alternative transportation, kitchen gas sales, and the illegal distribution of cable TV signals. These groups were known as "militias," a category that sought to capture the specificity of a type of social formation that began to spread through low-income neighborhoods and communities in Rio de Janeiro since the decade of 2000.

Souza $^{11} \&$ Silva $^{12}$ suggest thatthe area of privileged expansion of these groups are the illegal and irregular subdivisions located in the peripheries of the Rio de Janeiro metropolitan region, where groups rose supported by public agents who came to illegally divide and sell lots. The authors also affirm that the militias originated from groups of "justiceiros" [vigilantes], who came to sell an urbanization model based on "security".

Zaluar \& Conceição ${ }^{13}$ \& Misse $^{5}$ point to a continuity between the phenomenon of the militias and those known, since the 1960s, as "extermination groups." For these authors, the difference would be in the expansion of economic activities, broadening the supply of services; in the systematic chargingof the residents of certain regions, to the degree that the extermination groups were paid only by merchants who requested homicides; and in the formation of networks within the legislative and executive branchesand even in the judiciary. In fact, the moral justification triggered by these groups to legitimate the practices of extortion and exploitation of basic services was, in principle, that they would prevent drug dealers from operating in certain areas. This justification was for a long time accepted by the press, various politicians and sectors of the population. One example of thiswas found in 2006 when the mayor of Rio de Janeiro at the time publically referred to the militias as an element of "community selfdefense." The militias were represented in this way for a few years, based mainly on the pioneer experience of what at the time was called the "polícia mineira" [police who practice extortion when offering protection]in the community of Rio das Pedras, in the western zone of Rio de Janeiro. ${ }^{14}$

It is important to note that although the rise of militias was supported by the argumentof protection from the action of dealers, the social control exercised by militias proved to be as arbitrary and violent as that of the drug traffickers. In addition to demanding the monopoly of violence in certain areas, the militias used physical coercion and homicides to impose their command over the population. Even so, these groups were for a long time interpreted as a "lesser evil"when compared with drug dealers. The point of inflection in the perception that is made of the militias took place in April 2008 when journalists from the newspaper "O Dia" conducting an investigative report in the favela of Batam, a suburb ofRealengo, were kidnapped and tortured by militia members. There had been previous charges that members of this type of group committed coercion of the population and homicides, and a request had been made for the establishment 
of a parliamentary investigative commission $\mathrm{CPI}^{15}$ in the Rio de Janeiro state assembly to examine the involvement of legislators and other public agents in these events. Nevertheless, it was the clamor generated by the violence against the journalists that triggered the legislative investigation, supported by the press and public opinion.

The state assembly investigation had access to official documents from the civil police and public ministry (the state attorney general) and from more than one thousand complaints made between June and November 2008 to a phone line known as "Dial Militia," or on another phoneline known as "Dial a Complaint." Two hundred and eighteen people were indicted, including a state legislator and five city councilmen who lost their mandates, and 879 were "notified," but for whom there was not sufficient proof for an indictment. Among those indicted, 67 were members of the military police, 8 worked in the civil police and some were linked to other public agencies. The media visibility that the $\mathrm{CPI}^{15}$ gave to the issue of the militias modified how they came to be conceived by the population and repressed by the state. It was demonstrated that of the 171 communities controlled by militias, 119 had never belonged to drug factions, contradicting the thesis that they were a form for fighting drug dealing. The $\mathrm{CPI}^{15}$ also made clear the participation of government employees in these groups, the crimes that they practiced - mainly extortion and homicide - and the power of controlof the votes of the residents of the areas under their control.

\section{Social accumulation of violence}

What I have called, in my studies, the "social accumulation of violence"refers to a social process that has already lasted approximately half a century. It can be historically demarcated between the 1950 s and today. This process took place in the city of Rio de Janeiro and its immediate area of influence the Rio de Janeiro metropolitan region but has, in some moments, reached other cities of the state, capitals of other states and other Brazilian cities, acquiring potential national scope. While in other cities the process always shares similarities with the situation in Rio de Janeiro, the local developments have certain particularities. Here I present in general lines, the results of my studies about this process in Rio de Janeiro, which served as a model for my analysis. But it is first necessary to define the concepts that I have used in its understanding.

What I call "social accumulation"designates a complex of factors, a syndrome, which involves acumulative causal circularity. ${ }^{16}$ To isolate these factors is notan easy task, because they are cumulatively intertwined and any attempt to analytically separate them leads at times to superficial or tautological results. To deal with this difficulty, I needed to propose concepts that unite different theoretical contributions, combining them with the empirical material found. Thus, for example, since it is very common in Brazil for the law to not be followed in certain and varied cases, and since the contexts at times produce forms that standardize relatively legitimate extra-legal practices, it does not make sense to understand the limit of the social construction of crime to be within the criminalization process and acceptthe terms codified by the current positive law. It is necessary to go farther and recognize the concrete forms by which the practices and their social representations combine, in each case, processes of accusations and justification, crimination and de-crimination, incrimination and discrimination which, inside or outside the state, remain relatively autonomous in relation to the codified law and in a permanent tension with it.
The idea of the "social accumulation of violence" is simple. It refers to a process analog to the traditional "vendetta", inwhich violence accumulates when it is used to contain or revenge other violence. There is a popular expressionthat says that violence generates more violence. The novelty in the idea of social accumulation of violence is that it incorporates in the concept of violence the socially constructed content of the social, and native representation of violence, as in that popular expression, and its effects amplified by the contemporary media. In this way, the media also came to constitute itself as a social actor in this process and not only its journalistic spectator. The sense of the word violence expands, gains new forms based on its more traditional core - that of physical aggression and comes to have, depending on who is speaking or to whom or to what it is attributed - a complex and polysemic scope, part of which is criminalizable (concerning individuals and firms) and another part not (concerning states, social institutions, "social structures"). Individuals, social groups or firms may be violent, but violence can also be attributed - in social representations - to states, state institutions, such as the police and to other social institutions - churches, family, school andat the same time, to broader collective formations such as the economic system or the social structure. The main actors of the modern processof social accumulation of violence are the state, in particular the authorities responsible for criminal justice, especially the police, and their object of action, the subjects of violence, which are usually criminalizable. The entire balance of the interplay of language involved in the pairing of justice and violence depends on the modern criminal law andon its capacity to substitute the will of revenge for the will of legal punishment.

In this sense, following the tracks of known sociological contributions (Lemert, Becker, Cicourel, Goffman, Turk, etc.), I proposedthat the processof criminalization be distinguished in four moments: the "criminalization"per se, through which a certain course of action comes to be considered a crime, after a successful public campaign or as a resultof tradition. This involves its legal definition, as anideal-typewhich exists only in the codified reference and in the classifications of social representation. But, coherent or not with "criminalization"and its legal procedures, we have the effective processes through which events are interpreted as "crimes,"that is, fit into the legal classification.

To distinguish the first, I call them "crimination processes"and they can be interpreted as legal or extra-legal and should always be interpreted contextually. Once there is "crimination" of an event, that is, once the event is interpreted as a "crime," it then passes without an interval that is not analytical - to "incrimination", that is, to the nomination of its authorship, to the search for and punishment of its causal subject. This does not only involve a legal chronology, which leads criminalization to crimination and incrimination - this is a rational legal direction. As is known, in social practices incrimination can preventively anticipate crimination: before there is a crime, there is a potential criminal of this crime who can be incriminated. In the same way, before there is criminalization, there is a moral accusation of the conduct of someone and it is from this that is mobilized the venturesome - in specific events - who seek the ideal-typedefinition of a course of action as a codifiable crime.

When the incrimination anticipatesthe crimination (and even criminalization) of a regular and extra legal form, that is, when one passes directly from the accusation to incrimination even without any event that had been "criminated," that is, interpreted as a crime, the 
focus then shifts from the event to the subject and from the crime to the virtual criminal. This passage, which Foucault interpretedas derived from the passage of the law to the norm, creates the possibility that a subject becomes identified with "crime in general"and that he (and his extensions as a social type) come to incarnate the "crime" that has still not occurred.

In Brazil, the extra-legal prevalence of this process is generalized. It is notan exception, but a rule. To distinguish this social process from a rational-legal incrimination process, I call it "criminal subjection." It primarily seeks the subject of a crime that has not still not occurred. If the crime has already occurred and if this subject was already previously incriminated, for another crime, he becomes a "subjectwith a propensity to crime"and therefore a potential subject. If his social characteristics can be generalized to other subjects like him, a stigmatized "social type"is created. But criminal subjection is more than stigma, because it does not refer only to the labels, to the discredited social identity. It is an entire processof subjectivation that follows its course inthis internalization of the crime in the subject that supports and carries it like a "spirit"that he has in his body and soul. It is not by chance that in Brazil, the so-called "resocialization" of criminal subjects is conducted primarily through religious conversion ${ }^{5}$.

This substantive inequality that permeates the entire belief system about incrimination in Brazil and which characterizes a large portion of the "legal sensibility"in all the social classes, is increasingly articulated, on one hand, to the sense of insecurity, which is expanding, andon the other, to a conceptof incriminationbased on criminal subjection. These are some aspects, presented still in an abstract form, of the social accumulation of violence to which I referred at the beginning.

It is for no other reason that in my view the incorporation of the indiscriminate use of violence against suspects who come from the lower classes has reinforced, within the police forces, the certainty of impunity, especially when this violence is exercised as partof the social process of corruption. But as this violence gained legitimacy in reasonable sectors of the police and society, corruption was also no longer represented as a deviation but has acquired the reputation of a legitimate exchange. With guilt neutralized, the exchange comes to be openly realized in different contexts, always with the same justification that leads business leaders and professionals to not pay their taxes: "don't give money to corrupt governments and politicians."

These exchanges are expanded in such a way that, in the illegal markets, they come to be imposed by state agents, such as inspectors and the police, on the infractors, as a form of extortion, but with a degree of adhesion to the "positive sense" of this type of exchange by the partof the infractors. It thus constitutes a second legal market, a parasite of the first, which comes to offer "political goods"to drug dealers, weapons and other illegal merchandise. The scope of these practices in Brazil, on various institutional levels, led me to develop the conceptof "political merchandise,"1 which proposes to depict a formof exchange that involves costs and strategic negotiation (political but not necessarily through the state), and not only economic dimensions strictu sensuin the conformation of the exchange value of this type of merchandise. It is a modality of exchange that at the lower limit is a type of clientelism, while in intermediary cases it involves the offer of protection in illegal markets, andon a higher level becomes a formof extortion.

${ }^{5}$ There are studies that indicate the regularity of these conversions, mainly through affiliation rituals coordinated by neopentecostal pastors, when there is an exorcism of the "evil spirit." Cf. Teixeira. ${ }^{17} 2012$.

\section{Conclusion}

Upon completing this article, I would like to add that I am not referring to criminality in general, but to violent crimes, especially those related to the controlof urban territories by armed gangs, whether they are drug traffickers, or the police or other public agents. Only in Brazil, especially in Rio de Janeiro, has it become common to have an extensive territorialization of retail drug sales. These territories, operated by retail traffickers, are constituted in Rio de Janeiro by the points of sale on the hillsides ("bocas de fumo"), guarded by "soldiers" armed with rifles, machine guns, grenades and even in some cases, anti-aircraft weapons, all of this in an urban environment with high demographic density and constant police incursions. The armed conflicts with the police are followed by armed conflicts with other gangs, which try to invade and take each other's "territory."

In the past thirty years, a true arms race has led to a concentration of weapons of war on the hillsides and favelas that until today still challenge the police and the armed forces. But the defense of these "territories" does not involve political or collective objectives, the interest is only economic and military. A "warrior" perspective has been incorporated to these networks of small drug dealers, ${ }^{18}$ who confront each other and the police, dividing themselves into factions sustained by their function as protection agencies within the penitentiary system. They are mostly youth, with an average age between 15 and 19, who rarely surrender to the police: they prefer to run the risk of death, in any armed confrontation with the police than to surrender and go to prison. I do not find any better explanation for this than the perverse effect of criminal subjection, which has created generalized distrust among dealers and thieves - the main clientele of Brazilian prisons -than "a good bandit is a dead bandit."

The social accumulation of violence continues in Rio de Janeiro, with the migration of some of the youth dealers to assaulting pedestrians, buses and cars, and with the appearance of a new modality of "death squad", groups of military police that impose the offer of protection in favelas and poor housing projects, with the promise of killing the local bandits, in exchange for regular monthly payments. ${ }^{19,20}$ The residents who refuse the extortion have their houses invaded and ransacked, when they are not threatened with revenge. And these groups, which the press calls "militias", intend to substitute the drug dealers, even assuming partof the illegal sales that they had practiced.

From 2001 to 2011 alone, the Rio de Janeiro police officially recognized that it had killed more than 10 thousand civilians in armed conflicts on the hills and in the favelas, but as a justification,identified the victims as "bandits" and "traffickers." Since they are drug dealers and since they respond by shooting at the police, they can legally be killed, although in some cases there are indications that victims were shot from close-up.

Since the 1990s, my studies have focused on articulating the criminal subjection to the illegal markets in regions of urban poverty, to political merchandise and to violent police repression, to understand the social accumulation of violence in Rio de Janeiro. ${ }^{21,22}$ To understand why the Rio de Janeiro justice system is not able to solve $90 \%$ of the homicides in the city and state each year is what we are studying now. I suspect that this is also linked to criminal subjection, to the degree to which a large portion of the victims of these homicides have the same profile as the potential criminals and to solve their murders, when society was already indifferent about their lives, is of no interest to the police or to society as a whole. 
As many say coldly and with satisfaction in Brazil, "One less!"when commenting on the news about the death of a thief. Many also do not consider that by doing so, they actively participate in the murder andindifference in solving it and punishing the authors. They treat the victim as someone "who could be killed."They also participate actively in the possibility that, in an assault, the mugger does not only want their jewelry and money, but also wants, out of revenge or indifference, to take their lives. It is not rare that this occurs.

\section{Acknowledgements}

None.

\section{Conflict of interest}

The author declares no conflict of interest.

\section{References}

1. Misse M. Malandros, marginais e vagabundos. A acumulação social da violência no Rio de Janeiro. IUPERJ, Tese de Doutorado em Sociologia. Brazil; 1999. 413 p.

2. Misse M. Crime e Violência no Brasil Contemporâneo. Estudos de sociologia do crime e da violência urbana. In:Lumen Juris (Ed.), Rio de Janeiro, Brazil; 2006.

3. Misse M. "Crime, Estado y Mercancías Políticas en Brasil”. In: Daniel Miguez, Michel Misse, editors. e Alejandro Isla comp Estado y Crimen Organizado en América Latina. Argentina; 2014.

4. Misse M, Grillo CC. "Rio de Janeiro: Sofrir la violencia, decir la paz". In: Anamaria Jaramillo y, Carlos Mario Perea, comp, editors. Ciudades en la Encrucijada. Colombia: Corporación Región y Universidad Nacional de Colombia; 2014. 332 p.

5. Misse M. "Estado y mercados ilegales en Latinoamérica:reflexiones a partir del concepto de mercancia política". In: Jorge Giraldo Ramirez, editor. Economía Criminal y Poder Politico. South America: Universidad Eafit; 2012.

6. Chazkel A. Laws of Chance. Brazil's Clandestine Lottery and the Making of Urban Public Life. USA: Duke University Press; 2011. 368 p.
7. Amorim C. Comando Vermelho. Record, Rio de Janeiro, Brazil; 1995.

8. Zaluar A. Condomínio do Diabo. Rio de Janeiro, Brazil; 1995. 139 p.

9. Coelho EC. Oficina do Diabo e outros escritos. Record, Rio, Brazil; 2004.

10. Grillo CC. Coisas na Vida do Crime. Tese de Doutorado em Antropologia IFCS-UFRJ-PPGSA. Rio de Janeiro, Brazil; 2013. 291 p.

11. Souza JCA. "Milícias:mudanças na economia política do crime no Rio de Janeiro" in Vários autores, Segurança, Tráfico e Milícias. Brazil: Justiça Global e Fundação Heinrich Boll; 2008. 108 p.

12. Silva LAM. Vida sob cerco: Violência e rotina nas favelas do Rio de Janeiro. In: Nova Fronteira, editor. Brazil: FAPERJ; 2008.

13. Zaluar A, Conceição IS. "Favelas sob o controle das milícias no Rio de Janeiro". São Paulo em Perspectiva. 2007;21(2):89-101.

14. Burgos M. A Utopia da Comunidade Rio das Pedras, uma favela carioca. Brazil: PUC Rio e Edições Loyola; 2002.

15. CPI. Relatório da Comissão Parlamentar de Inquérito sobre as Milícias Brazil: Assembleia Legislativa do Estado do Rio de Janeiro; 2008.

16. Myrdal G. O valor em teoria social. Brazil: Pioneira; 1961.

17. Teixeira CP. “' 'Frios', 'pobres' e 'indecentes':esboço de interpretação de alguns discursos sobre o criminoso". In: Michel Misse, Alexandre Werneck, editors. Conflitos de grande interesse. Rio de Janeiro, Brazil; 2012. 360 p.

18. Zaluar A. Integração Perversa: pobreza e tráfico de drogas. Rio de Janeiro, Brazil; 2004.

19. Cândido A. Brigada Ligeira. Brazil: Anhembi; 1959.

20. Cano I. "Seis por meia dúzia? Um estudo exploratório do fenômeno das chamadas 'milícias' no Rio de Janeiro in: Vários autores, Segurança, Tráfico e Milícias. Brazil: Justiça Global e Fundação Heinrich Boll; 2008.

21. Rafael A. Um abraço para todos os amigos. Algumas considerações sobre o tráfico de drogas no Rio de Janeiro. Brazil: EDUFF; 1998.

22. Vargas JD, Misse M. "L'évolution de la consommation et du trafic de drogues illicites à Rio de Janeiro". Déviance et Société. 2008;32(3):377391. 